\title{
Zooplankton diversity analysis through single-gene sequencing of a community sample
} Ryuji J Machida*1, Yasuyuki Hashiguchi ${ }^{2}$, Mutsumi Nishida ${ }^{1}$ and Shuhei Nishida ${ }^{1}$ \author{
Osaka Medical College, Daigaku-machi 2-7, Takatsuki, Osaka 569-8686, Japan \\ Email: Ryuji J Machida* - ryuji@ori.u-tokyo.ac.jp; Yasuyuki Hashiguchi - bio007@art.osaka-med.ac.jp; \\ Mutsumi Nishida - mnishida@ori.u-tokyo.ac.jp; Shuhei Nishida - nishida@ori.u-tokyo.ac.jp \\ * Corresponding author
}

Address: ${ }^{1}$ Ocean Research Institute, University of Tokyo, 1-15-1 Minamidai, Nakano-ku, Tokyo 164-8639, Japan and ${ }^{2}$ Department of Biology,

Published: 17 September 2009

BMC Genomics 2009, 10:438 doi:10.1186/147|-2164-10-438
Received: 6 August 2008

Accepted: 17 September 2009

This article is available from: http://www.biomedcentral.com/I47I-2/64/I0/438

(c) 2009 Machida et al; licensee BioMed Central Ltd.

This is an Open Access article distributed under the terms of the Creative Commons Attribution License (http://creativecommons.org/licenses/by/2.0), which permits unrestricted use, distribution, and reproduction in any medium, provided the original work is properly cited.

\begin{abstract}
Background: Oceans cover more than $70 \%$ of the earth's surface and are critical for the homeostasis of the environment. Among the components of the ocean ecosystem, zooplankton play vital roles in energy and matter transfer through the system. Despite their importance, understanding of zooplankton biodiversity is limited because of their fragile nature, small body size, and the large number of species from various taxonomic phyla. Here we present the results of single-gene zooplankton community analysis using a method that determines a large number of mitochondrial $\mathrm{COI}$ gene sequences from a bulk zooplankton sample. This approach will enable us to estimate the species richness of almost the entire zooplankton community.
\end{abstract}

Results: A sample was collected from a depth of $721 \mathrm{~m}$ to the surface in the western equatorial Pacific off Pohnpei Island, Micronesia, with a plankton net equipped with a $2-\mathrm{m}^{2}$ mouth opening. A total of I,336 mitochondrial $\mathrm{COI}$ gene sequences were determined from the cDNA library made from the sample. From the determined sequences, the occurrence of 189 species of zooplankton was estimated. BLASTN search results showed high degrees of similarity $(>98 \%)$ between the query and database for 10 species, including holozooplankton and merozooplankton.

Conclusion: In conjunction with the Census of Marine Zooplankton and Barcode of Life projects, single-gene zooplankton community analysis will be a powerful tool for estimating the species richness of zooplankton communities.

\section{Background}

The fauna of the world's oceans is dominated in terms of abundance and biomass by drifting organisms collectively referred to as plankton. Plankton occur in all marine waters, throughout all depths, and, for many species, across widespread biogeographical regions. Zooplankton (planktonic animals) support many major fisheries and mediate fluxes of nutrients and chemical elements essential to life on earth. Despite more than a century of sampling the oceans, a comprehensive understanding of zooplankton biodiversity has eluded oceanographers because of the fragile nature and small body size of these organisms, as well as the large number of species from various taxonomic phyla $[1,2]$. For many zooplankton 
groups, there are longstanding and unresolved questions of species identification, systematic relationships, genetic diversity, and biogeography. In light of this, we are working toward a taxonomically comprehensive assessment of zooplankton biodiversity throughout the world's oceans through the international project Census of Marine Zooplankton [3].

\section{Results and Discussion}

A zooplankton sample was collected off Pohnpei Island, Micronesia $\left(6^{\circ} 16^{\prime} \mathrm{N}, 162^{\circ} 09^{\prime} \mathrm{E}\right)$. A cDNA mitochondrial COI (cytochrome c oxidase subunit I) gene library was constructed from the sample, and 1,336 inserts containing the mitochondrial $C O I$ gene were randomly sequenced [DDBJ: AB332438-AB333773]. A cDNA rather than a gDNA library was constructed to remove pseudogene sequences from the analysis [4]. The mismatch distribution of these 1,336 sequences revealed a high frequency of very small $(<0.03)$ genetic distance sequence pairs (Figure $1)$. These sequence pairs with very small genetic distances were assumed to have originated from the same species (discussed below). A second peak was observed around a distance of about 0.14 (from 0.13 to 0.16 ), and most of these counts were comparisons between two phylogroups in the Copepoda clade (Figure 2, Clades 1 and 2). The frequencies between these peaks were very low. The minimum frequency (106 counts) was observed in the range between 0.12 and 0.13 . Based on this observation, we set the criterion that if the genetic distance of two sequences was greater than 0.12 , the sequences were derived from different species. If the genetic distance of two sequences was less than 0.12 , then we considered the sequences to be derived from the same species. The genetic distances of the mitochondrial COI gene sequence have been reported from various animal taxa (mainly Vertebrata and Arthropoda), and the general ranges for the intra- and interspecies distances are 0.0001-0.05 and 0.04-0.21, respectively (Kimura two-parameter model) [5]. Although it is not a conclusive value for animal species definition, we have tentatively taken a genetic distance of 0.12 as the boundary between intra- and interspecies distances in this study, and this value was in the range of interspecific genetic distance reported previously [5]. The rarefaction curve was estimated using the criterion of a genetic distance of 0.12 (Figure 3) using DOTUR [6]. Although the number of observed OTUs is still growing in 1,300 sequenced colonies, the rate of increase of the curve decreased gradually after around 100 sequenced colonies. Figure 4 shows the relationships between species richness estimated by Chao1, rarefaction, and percentage of sequence differences used for the estimation. The figure shows gradual changes of Chao 1 and rarefaction around sequence differences of 0.12 . As the distance of 0.12 is not a conclusive value for species definition, caution is required in the further use of this value.

We conducted BLASTN searches against the GenBank non-redundant database using as queries all sequences derived from the analysis. Among the sequences, those that fulfilled the criteria (BLAST score and similarity greater than 100 and $83 \%$, respectively) were assigned to 11 taxonomic groups (Figure 2). Several of the assigned sequences showed very high degrees of nucleotide similarity to known species, including Copepoda (Candacia

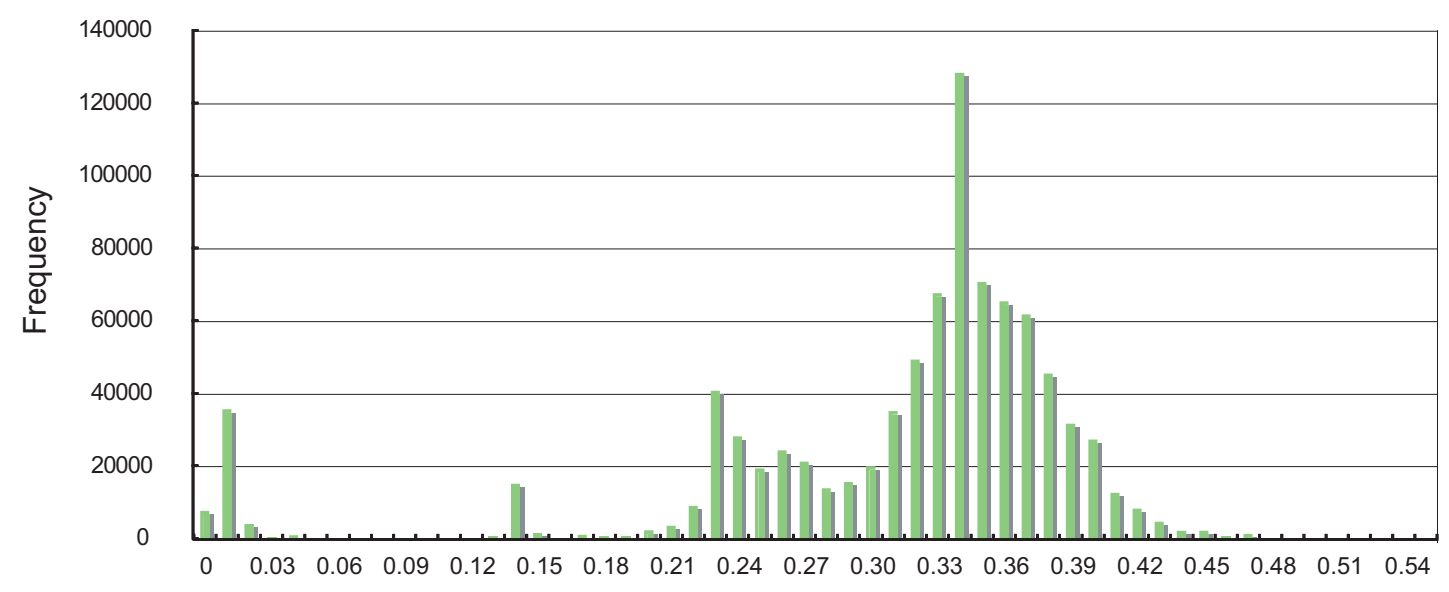

Genetic distance $(p)$

\section{Figure I}

Mismatch distributions of the pairwise genetic distances for the I,336 mitochondrial COI sequences. A total of 891,780 frequencies calculated from the I,336 sequences are plotted in the figure. 


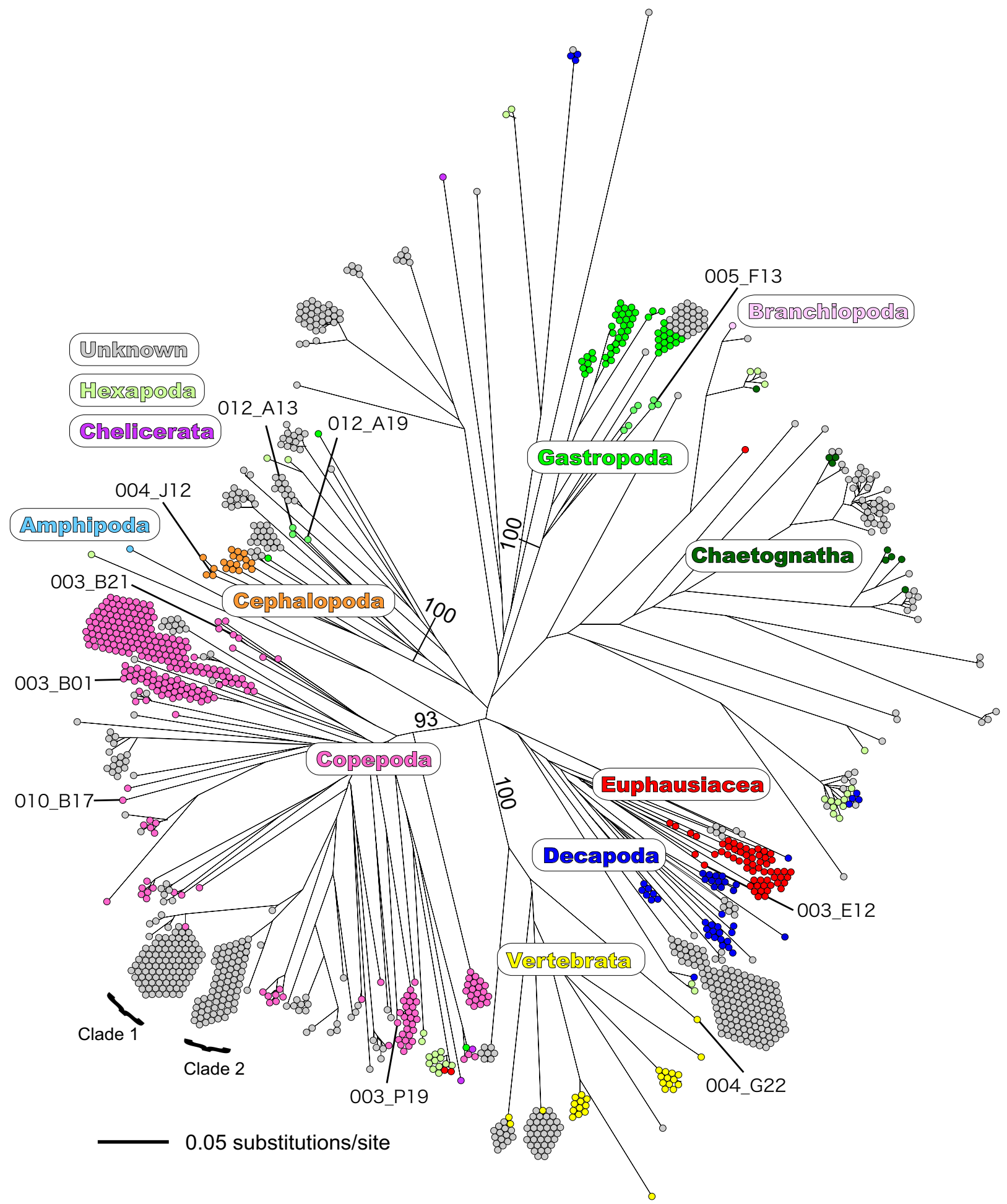

Figure 2

Unrooted neighbour-joining tree of the I,336 mitochondrial COI gene sequence. Numbers beside internal branches indicate bootstrap values (>90\%) obtained for I,000 replicates (indicated for major branches only). Each dot represents a single mitochondrial $\mathrm{COl}$ gene sequence. Colour of each dot represent the higher taxonomic groups denoted in the figure with the criterion of the score and similarity more than 100 and $83 \%$, respectively, in the BLAST results. 


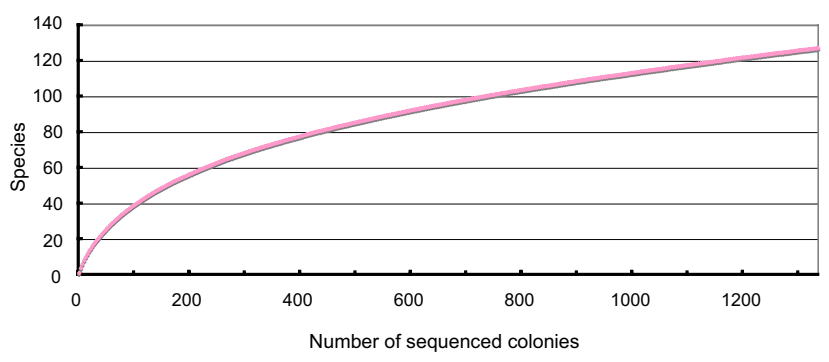

Figure 3

Rarefaction analysis of the 1,336 mitochondrial $\mathrm{COI}$ gene sequences.

longimana, Cosmocalanus darwinii, Neocalanus robustior, Rhincalanus rostrifrons), Euphausiacea (Stylocheiron carinatum), Mollusca (Clio pyramidata, Sthenoteuthis oualaniensis, Strombus mutabilis, Strombus wilsoni), and Vertebrata (Coryphaena hippurus; Table 1). The very high degrees of similarity indicated that these species were actually collected in our sampling. Among them, one vertebrate species, Coryphaena hippurus, and two benthic gastropod species, Strombus mutabilis and Strombus wilsoni, were sampled as nonholozooplanktonic animals in the dispersal life history phase as pelagic larvae. These observations indicated that application of this analysis enables the estimation of larval dispersal, which is difficult to achieve based on morphological observations.

Figure 2 shows an unrooted neighbour-joining tree of the 1,336 zooplankton COI sequences. Overall, each taxo-

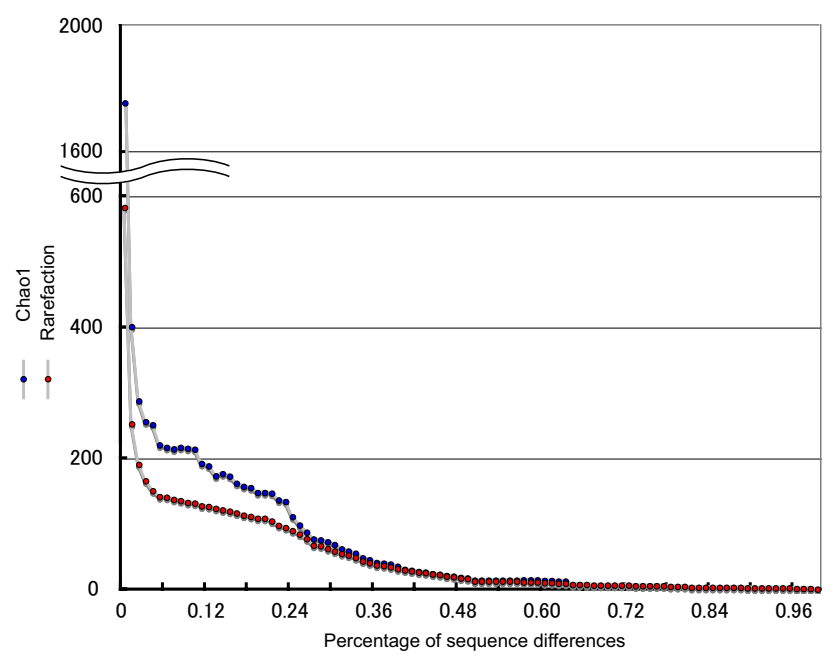

\section{Figure 4}

Relationship between species richness estimated by Chaol, rarefaction, and the percentage sequence difference used for these estimations. nomic group formed a single cluster including Gastropoda, Chaetognatha, Euphausiacea, Decapoda, Vertebrata, Copepoda, and Cephalopoda. There were also two cases in which the taxonomic assignment did not work well. The first was the occurrence of Hexapoda in various clusters, which rarely occurs in the ocean environment, except pleustonic insects of the genus Halobates. The second was the difficulty of assignment of taxonomic groups due to low BLAST scores and similarities (coloured grey in Figure 2 ). The most plausible reason for these ambiguities is the paucity of mitochondrial $\mathrm{COI}$ sequences for some taxa in the DNA database. In general, the mitochondrial COI gene sequences in the DNA database are biased among taxa, and this bias was assumed to be the main reason for the occurrence of Hexapoda in our analysis. The most efficient solution for these problems will be the expansion of zooplankton DNA barcode, and it is hoped that the progress of the Barcode of Life project [7] in collaboration with the Census of Marine Zooplankton will fill these gaps.

To our knowledge, the Discovery SOND cruise [8] is the only other attempt to date to estimate the species richness of a whole zooplankton community collected at a single site. In this series of studies [9-19], a total of 618 species of zooplankton were identified and counted in samples collected around the Canary Islands (Table 2). The extrapolated species richness (Chao1 [20]) of the present study was estimated as 188.90 (95\% confidence interval, 156.79-255.60) using DOTUR [6]. Our results cannot be directly compared with the SOND cruise data because of differences in sampling effort between the two studies. In the SOND cruise, two primary types of sampling equipment were used: Isaacs-Kidd midwater trawl and N113H.

Furthermore, about 76 vertically stratified zooplankton samples that were collected above $1,000 \mathrm{~m}$ were combined to estimate the occurrence of species [19]. In contrast, the present study was conducted based on a single sample collected from a depth of $721 \mathrm{~m}$ to the surface. These sampling effort differences may have accounted for the differences in species richness between the SOND cruise and the present study. In addition, the lower species richness in the present study may have been due to our experimental design. In the present study, after construction of the cDNA library from mRNA, the mitochondrial COI genes were amplified with "universal (LCO1490 [21])" and polyT primers. It is possible that some of the mitochondrial COI gene sequences may not have been amplified due to primer mismatch for some species. Although the single-gene zooplankton community analysis approach is an efficient means of collecting sequence information, given technical difficulties due to primer mismatch, further studies and the development of novel 
Table I: BLASTN search results for sequences that showed more than $98 \%$ similarity to subject sequences

\begin{tabular}{|c|c|c|c|c|c|c|}
\hline Colony Number & Accession Number & Subject Species & Score & E-value & Identity & Similarity (\%) \\
\hline \multicolumn{7}{|l|}{ Copepoda } \\
\hline 003_PI9 & AY|45435 & Candacia longimana & 959 & 0 & $496 / 500$ & 99 \\
\hline 003_B2I & AF4623II & Cosmocalanus darwinii & 902 & 0 & $479 / 487$ & 98 \\
\hline $003 \_L 24$ & AYI44465 & Neocalanus robustior & 940 & 0 & $486 / 490$ & 99 \\
\hline 010_BI7 & AY371094 & Rhincalanus rostrifrons & 597 & $2 e-167$ & $307 / 309$ & 99 \\
\hline \multicolumn{7}{|c|}{ Krill (Euphausiacea) } \\
\hline 003_EI2 & AF371987 & Stylocheiron carinatum & 944 & 0 & $491 / 496$ & 98 \\
\hline $\begin{array}{l}\text { Mollusca } \\
005 \_F 13\end{array}$ & DQ238000 & Clio pyramidata & 898 & 0 & $468 / 473$ & 98 \\
\hline 2004_ال_ا2 & DQ88584I & Sthenoteuthis oualaniensis & 967 & 0 & $497 / 500$ & 99 \\
\hline $012 \_A \mid 3$ & DQ525218 & Strombus mutabilis & 938 & 0 & $485 / 489$ & 99 \\
\hline 012_A19 & DQ525214 & Strombus wilsoni & 906 & 0 & $48 I / 489$ & 98 \\
\hline \multicolumn{7}{|l|}{ Vertebrata } \\
\hline 004_G22 & DQ027995 & Coryphaena hippurus & 950 & 0 & $485 / 487$ & 99 \\
\hline
\end{tabular}

methodologies are required to gain a complete understanding of zooplankton diversity.

\section{Conclusion}

Although the estimation of species richness and composition of the community are among the most important aspects of single-gene zooplankton community analysis, these sequence data will be further utilised by construction of a dedicated database. We expect that the accumulation of additional marine animal mitochondrial COI gene sequence data in the barcode project will aid in further clarifying sequences from unknown species. Furthermore, this process of sequence assignment to particular species through database analysis indicated the occurrence of these species in the sampling site for the present study. We have now constructed a publicly accessible zooplankton community analysis database that can be searched using BLASTN [22].

With regard to the future of zooplankton community genetic analysis, adoption of next-generation sequencing technology should enable researchers to read libraries sufficiently to estimate species richness without extrapola-

Table 2: Comparison of species that occurred in the present study and the SOND cruise

\begin{tabular}{lll}
\hline Taxa & Present Study (\%) & SOND Cruise (\%) \\
\hline $\begin{array}{lll}\text { Amphipoda } \\
\text { Cephalopoda }\end{array}$ & $4(2.1)$ & $106(17.2)$ \\
$\begin{array}{l}\text { Copepoda } \\
\text { Decapoda }\end{array}$ & $81(42.2)$ & $18(2.9)$ \\
$\begin{array}{l}\text { Euphausiacea } \\
\text { Gastropoda }\end{array}$ & $8(4.2)$ & $35(5.6)$ \\
$\begin{array}{l}\text { Ostracoda } \\
\text { Siphonophora }\end{array}$ & & $28(4.5)$ \\
Vertebrata & $11(5.7)$ & $35(5.7)$ \\
\hline Total & 192.47 & $64(10.4)$ \\
$112(18.1)$
\end{tabular}

tion $[23,24]$. We are currently expanding our sampling effort to all oceans to further understand zooplankton biodiversity.

\section{Methods}

\section{Zooplankton sampling}

The sample was collected off Pohnpei Island, Micronesia $\left(6^{\circ} 16^{\prime} \mathrm{N}, 162^{\circ} 09^{\prime} \mathrm{E}\right)$. Collection was performed with a plankton net (ORI net [25]) with a $2-\mathrm{m}^{2}$ mouth opening and $0.69-\mathrm{mm}$ mesh aperture. After removal of large animals (more than about $4 \mathrm{~cm}$ at their largest measurement), the sample was split into two fractions: one was preserved in ethanol for barcode analysis and the other was homogenised with TRIZol (Invitrogen) and kept at $80^{\circ} \mathrm{C}$. A total wet volume of about $30 \mathrm{~mL}$ zooplankton was collected and homogenised with $270 \mathrm{~mL}$ TRIZol in this step.

\section{Total RNA extraction and mRNA purification}

In the laboratory, total RNA was extracted from the sample following the TRIZol protocol, followed by mRNA purification using Poly(A)Purist MAG (Ambion). A total of $9.6 \mathrm{~mL}$ total RNA (aqueous phase) was further purified for mRNA in this step.

\section{Mitochondrial COI gene library construction and sequence analysis}

The purified mRNA was used as the template for Creator SMART cDNA Library Construction Kit (BD Biosciences). Using this constructed cDNA library, we amplified mitochondrial COI genes using COI universal (LCO1490) [21] and polyT primers with restriction sites that were further used to construct a mitochondrial COI gene library with the same kit. We then randomly analysed colonies obtained on agar plates.

\section{BLASTN search and taxonomic assignment}

The lengths of all obtained sequences were adjusted to 500 base pairs, and a BLASTN [26] search against the 
NCBI non-redundant dataset with default settings was performed with all sequences as queries. Those sequences that did not show any similarity to the mitochondrial COI gene sequences were removed (the search was performed in November 2006). BLASTN search against the NCBI non-redundant dataset was also used to infer species or higher taxonomic groups of mitochondrial COI gene sequences determined in the present study. In the BLASTN result list, the species with the highest score was assigned to each sequence with the following criteria. If the BLASTN score was 100 or more and BLASTN similarity was $98 \%$ or more, the name of the resulted species was assigned to the sequence and listed in table 1 . If the BLASTN score was 100 or more and BLASTN similarity was $83-98 \%$, the name of higher taxon group to which the resulted species belongs was assigned to the sequence and is shown in the figure 2. If BLASTN scores and similarity values did not reach these values of criteria, 'unknown' was assigned to the sequences and are colored gray in the figure 2 .

\section{Removal of PCR recombination, mismatch distribution analysis, rarefaction curve analysis, phylogenetic analysis} To remove sequences produced by PCR recombination, we manually applied a partial treeing approach [27] to the aligned dataset; although some programs and servers are available for related analysis, none worked appropriately for our analysis. Briefly, after the sequence alignment was adjusted using ClustalX [28], square distance matrixes of both the left 100 and right 100 base pairs of the aligned sequence were constructed in MEGA3.1 [29]. Then total absolute deviations of each sequence in these matrixes were calculated. As a result, we deleted one sequence that showed a very large deviation from the others. We assumed this was not the only chimera sequence that occurred in the analysis, but it was not possible to eliminate all PCR recombination sequences because of ambiguity. After removing the PCR recombination sequences from the analysis, we again adjusted alignment of the remaining 1,336 sequences using ClustalX. An unrooted phylogenetic tree was constructed using the neighbourjoining method with nucleotide p-distances (alignment gaps were completely deleted) implemented in PAUP* $4.10 \mathrm{~b}[30]$. The reliability of each tree node was assessed using the bootstrap method with 1,000 replicates. The mismatch distribution was estimated from the distance matrix. The distance matrix was also calculated using PHYLIP3.66 [31], and the matrix was further used for rarefaction curve and Chao 1 calculation using DOTUR [6].

\section{Authors' contributions}

R.J.M. was responsible for most of the project planning and experiments other than the BLASTN searches, which were performed by Y.H., M.N., and S.N., who were also responsible for directing the laboratories. The manuscript was prepared by R.J.M. and revised by all other authors.

\section{Acknowledgements}

We are grateful to the captains and crew members of the R. V. Hakuho Maru for their cooperation at sea. We gratefully acknowledge the support of the Alfred P. Sloan Foundation. Additional support for this project was provided to R.J.M. by a Grant-in-Aid for Scientific Research (No. 2024I 1003) from the Ministry of Education, Culture, Sports, Science and Technology of Japan. Data Integration \& Analysis System from the Ministry of Education, Culture, Sports, Science and Technology of Japan provided funding to R.J.M. and S.N. This study is a contribution from the Census of Marine Zooplankton, an ocean realm field project of the Census of Marine Life (CMarZ).

\section{References}

I. Miller CB: Biological Oceanography Oxford: Blackwell; 2004.

2. Bucklin A, de Vargas C, Hopcroft RR, Madin LP, Thuesen EV, Wiebe PH, Boltovskoy D, Haddock SHD, Hay SJ, Kideys A, Melle W, Nishida S, Ohman MD, Pagés F, Pierrot-Bults AC, Richardson AN, Schiel S: Science Plan for the Census of Marine Zooplankton 2004 [http:// www.cmarz.org].

3. Census of Marine Zooplankton [http://www.cmarz.org]

4. Bensasson D, Zhang DX, Hartl DL, Hewitt GM: Mitochondrial pseudogenes: evolution's misplaced witnesses. Trend Ecol Evol 200I, 16:3|4-32I.

5. Waugh J: DNA barcoding in animal species: progress, potential and pitfalls. Bioessays 2007, 29:|88-197.

6. Schloss PD, Handelsman J: Introducing DOTUR, a computer program for defining operational taxonomic units and estimating species richness. Appl Environ Microbiol 2005, 7I:150I-1506.

7. Consortium for the Barcode of Life [http://www.barcod ing.si.edu/]

8. Foxton P: SOND cruise 1965 - Biological sampling methods and procedures. J Mar Biol Ass UK 1969, 49:603-620.

9. Thurston $\mathrm{MH}$ : The vertical distribution and diurnal migration of the Crustacea Amphipoda collected during the SOND cruise, 1965. I. The Gammaridea. J Mar Biol Ass UK 1976, 56:359-382.

10. Thurston $\mathrm{MH}$ : The vertical distribution and diurnal migration of the Crustacea Amphipoda collected during the SOND cruise, 1965. II. The Hyperiidea and general discussion. J Mar Biol Ass UK 1976, 56:383-470.

II. Clarke MR: Cephalopoda collected on the SOND cruise. J Mar Biol Ass UK 1969, 49:961-976.

12. Roe HSJ: The vertical distributions and diurnal migrations of calanoid copepods collected on the SOND cruise, 1965. I. The total population and general discussion. J Mar Biol Ass UK |972, 52:277-3|4.

13. Foxton $P:$ The vertical distribution of pelagic decapods [Crustacea: Natantia] collected on the SOND cruise 1965. I. The Caridea. J Mar Biol Ass UK 1970, 50:939-960.

14. Foxton P: The vertical distribution of pelagic decapods [Crustacea: Natantia] collected on the SOND cruise 1965. II. The Penaeidea and general discussion. J Mar Biol Ass UK 1970, 50:961-1000.

15. Baker ADC: The vertical distribution of euphausiids near Fuerteventura, Canary Islands ('Discovery' SOND cruise, 1965). J Mar Biol Ass UK 1970, 50:30 I-342.

16. Angel MV: Planktonic ostracods from the Canary Island region; their depth distributions, diurnal migrations, and community organization. J Mar Biol Ass UK 1969, 49:5 I5-553.

17. Pugh PR: The vertical distribution of the siphonophores collected during the SOND cruise, 1965. J Mar Biol Ass UK 1974, 54:25-90.

18. Badcock J: The vertical distribution of mesopelagic fishes collected on the SOND cruise. J Mar Biol Ass UK 1970 , 50:1001-1044. 
19. Currie RI, Boden BP, Kampa EM: An investigation on sonic-scattering layers: The R.R.S. 'Discovery' SOND cruise, 1965. J Mar Biol Ass UK 1969, 49:489-5I4.

20. Chao A: Non-parametric estimation of the number of classes in a population. Scand J Stat 1984, I I:265-270.

21. Folmer O, Black M, Hoeh W, Luts R, Vrijenhoek R: DNA primers for amplification of mitochondrial cytochrome $c$ oxidase subunit I from diverse metazoan invertebrates. Mol Mar Biol Biotech 1994, 3:294-299.

22. CMarZ-Asia Database [http://www.cmarz-asia.org/db/]

23. Margulies M, Egholm M, Altman WE, Attiya S, Bader JS, Bemben LA, Berka J, Braverman MS, Chen YJ, Chen ZT, Dewell SB, Du L, Fierro JM, Gomes XV, Godwin BC, He W, Helgesen S, Ho CH, Irzyk GP, Jando SC, Alenquer MLI, Jarvie TP, Jirage KB, Kim JB, Knight JR, Lanza JR, Leamon JH, Lefkowitz SM, Lei M, Li J, Lohman KL, Lu H, Makhijani VB, McDade KE, McKenna MP, Myers EW, Nickerson E, Nobile JR, Plant R, Puc BP, Ronan MT, Roth GT, Sarkis GJ, Simons JF, Simpson JW, Srinivasan M, Tartaro KR, Tomasz A, Vogt KA, Volkmer GA, Wang SH, Wang Y, Weiner MP, Yu PG, Begley RF, Rothberg JM: Genome sequencing in microfabricated high-density picolitre reactors. Nature 2005, 437:376-380.

24. Bennett S: Solexa Ltd. Pharmacogenomics 2004, 5:433-438.

25. Omori M: A $\mathbf{1 6 0}-\mathbf{c m}$ opening - closing plankton net. J Oceanogr Soc Japan 1965, 21:212-220.

26. Altschul SF, Gish W, Miller W, Myers EW, Lipman DJ: Basic local alignment search tool. J Mol Biol 1990, 21 5:403-4I0.

27. Huber T, Faulkner G, Hugenholtz P: Bellerophon: a program to detect chimeric sequences in multiple sequence alignments. Bioinformatics 2004, 20:2317-23I9.

28. Thompson JD, Gibson TJ, Plewniak F, Jeanmougin F, Higgins DG: The ClustalX windows interface: flexible strategies for multiple sequence alignment aided by quality analysis tools. Nuc Acid Res 1997, 25:4876-4882.

29. Kumar S, Tamura K, Nei M: MEGA3: Integrated software for molecular evolutionary genetics analysis and sequence alignment. Briefings in Bioinf 2004, 5:150-163.

30. Swofford DL: PAUP*. In Phylogenetic Analysis Using Parsimony (*and Other Methods). Version 4 Massachusetts: Sinauer Associates; 2002.

3I. Felsenstein J: PHYLIP (Phylogeny Inference Package) Version 3.6. Seattle: Distributed by the author Department of Genome Sciences, University of Washington; 2004.
Publish with Bio Med Central and every scientist can read your work free of charge

"BioMed Central will be the most significant development for disseminating the results of biomedical research in our lifetime. "

Sir Paul Nurse, Cancer Research UK

Your research papers will be:

- available free of charge to the entire biomedical community

- peer reviewed and published immediately upon acceptance

- cited in PubMed and archived on PubMed Central

- yours - you keep the copyright
BioMedcentral 